\title{
Methods for selection of Daphnia resting eggs: the influence of manual decapsulation and sodium hypoclorite solution on hatching rates
}

\author{
T. A. S. V. Paes ${ }^{a}$, A. C. Rietzler ${ }^{a}$ and P. M. Maia-Barbosa ${ }^{a *}$ \\ aPostgraduate Programme in Ecology, Conservation and Management of Wildlife - ECMVS, \\ Laboratory of Limnology, Ecotoxicology and Aquatic Ecology, Universidade Federal de Minas Gerais - UFMG, \\ Av. Antônio Carlos, 6627, Pampulha, CEP 31270-901, Belo Horizonte, MG, Brazil \\ *e-mail: maia@icb.ufmg.br
}

Received: June 19, 2015 - Accepted: October 7, 2015 - Distributed: November 30, 2016

(Wtih 4 figures)

\begin{abstract}
Cladocerans are able to produce resting eggs inside a protective resistant capsule, the ephippium, that difficults the visualization of the resting eggs, because of the dark pigmentation. Therefore, before hatching experiments, methods to verify viable resting eggs in ephippia must be considered. This study aimed to evaluate the number of eggs per ephippium of Daphnia from two tropical aquatic ecosystems and the efficiency of some methods for decapsulating resting eggs. To evaluate the influence of methods on hatching rates, three different conditions were tested: immersion in sodium hypochlorite, manually decapsulated resting eggs and intact ephippia. The immersion in hypochlorite solution could evaluate differences in numbers of resting eggs per ephippium between the ecosystems studied. The exposure to sodium hypochlorite at a concentration of $2 \%$ for 20 minutes was the most efficient method for visual evaluation and isolation of the resting eggs. Hatching rate experiments with resting eggs not isolated from ephippia were underestimated $(11.1 \pm 5.0 \%)$, showing the need of methods to quantify and isolate viable eggs. There were no differences between the hatching rate of resting eggs submitted to hypochlorite solution $(47.2 \pm 7.34 \%)$ and manually decapsulated $(53.7 \pm 13.24 \%)$. However, the immersion in hypochlorite was a more efficient technique, faster and not requiring manual ability.
\end{abstract}

Keywords: Daphnia, ephippium decapsulation, techniques, resting eggs viability.

\section{Técnicas para seleção de ovos de resistência de Daphnia: influência do desencapsulamento manual e imersão em solução de hipoclorito nas taxas de eclosão}

\section{Resumo}

Cladóceros são capazes de produzir ovos de resistência envoltos por uma cápsula protetora, o efípio, que dificulta a visualização do número de ovos, devido à pigmentação escura. Assim, antes da condução de experimentos de eclosão, métodos para determinar o número de ovos de resistência viáveis no interior do efípio devem ser utilizados. Este estudo teve como objetivo avaliar o número de ovos por efípio de Daphnia de dois ecossistemas aquáticos tropicais e a eficiência de alguns métodos de desencapsulamento de ovos de resistência. Para avaliar a influência dos métodos na taxa de eclosão foram testadas três condições: imersão em hipoclorito de sódio, ovos de resistência desencapsulados manualmente e efípios intactos. A imersão em solução de hipoclorito permitiu avaliar as diferenças no número de ovos de resistência por efípios entre os ecossistemas. A exposição ao hipoclorito de sódio a uma concentração de $2 \%$ durante 20 minutos foi o método mais eficiente para a avaliação visual e isolamento dos ovos de resistência. A taxa de eclosão de ovos não isolados de efípios foi subestimada $(11,1 \pm 5,0 \%)$, mostrando a necessidade de métodos para quantificação e isolamento dos ovos. Não foi verificada diferença de eclosão entre os ovos isolados a partir da imersão em solução de hipoclorito (47,2 $\pm 7,34 \%)$ e manualmente desencapsulados (53,7 $\pm 13,24 \%)$. Entretanto, a imersão em hipoclorito é uma técnica mais eficiente, pois além de mais rápida, não necessita de destreza manual.

Palavras-chave: Daphnia, desencapsulamento de efípios, técnicas, viabilidade de ovos de resistência. 


\section{Introduction}

Most organisms live in changeable environments. To with stand these conditions, which can sometimes be lethal, some organisms have developed dormancy as a life-history strategy. Among the factors that interfere in diapause are: photoperiod and temperature (Vandekerkhove et al., 2005), temporary ponds (Panarelli et al., 2008), abiotic factors (Rojas et al., 2001), anthropic action (Maia-Barbosa et al., 2003), seasonal effects (Brandão et al., 2012) and salinity (Santangelo et al., 2014). Many zooplankton species, including cladocerans, use a variation of this strategy (Cáceres and Tessier, 2003). Diapause in cladocerans occurs through the production of resting eggs, which are deposited in the sediment and represents a temporary refuge or a reserve against adverse conditions, allowing the populations to reestablish after favorable conditions return.

For cladocerans, the production of dormant stages requires a change in the mode of reproduction. Most of the time, cladocerans reproduce by parthenogenesis, with cyclic production of diploid eggs. To form the dormant stage, the females stop producing diploid eggs and start to produce haploid eggs and males. The fertilized eggs originate the resistant form, while the unfertilized eggs degenerate and are reabsorbed by the mother (Zaffagnini, 1987). In Daphnia, the resting egg is enclosed by a chitinous shell called ephippium, that is formed from the dorsal shell of the mother and improves the resistance of resting eggs to adverse conditions (Ślusarczyk and Pietrzak, 2008). Chitin content of resting eggs varies from $17 \%$ to $25 \%$, as a consequence their durability is so high (Kaya et al., 2013; Kaya et al., 2014).

For these organisms, usually ephippial membranes contain two eggs, but this number may be variable and it is difficult to determine it visually (Zaffagnini, 1987). The variation in the number of resting eggs per ephippia can be explained by some factors: hatching (Fox, 2007), egg abortion (Conde-Porcuna et al., 2011) and no fertilization (in sexual Daphnia populations) (Zaffagnini, 1987). The proportion of empty ephippia varies substantially among localities and species (Vaníčková et al., 2010) and the proportion of resting eggs per ephipium varies with food availability (Conde-Porcuna et al., 2014). Visualization of the number of resting eggs per ephippia is difficult because ephippia are pigmented with melanin. The variation in pigmentation exists within and across populations and species, occurring more often in lakes with the highest ephippial production (Gerrish and Cáceres, 2003).

Therefore, studies with resting eggs must consider the use of methods to checking the number of eggs before hatching tests. Some investigators use a pair of needles to open each ephippium individually in order to select viable eggs (Davison, 1969; Cáceres, 1998; Cáceres and Tessier, 2003; Angeler, 2005) or sort the eggs under an inverted microscope without opening the ephippium (Pérez-Martínez et al., 2012). These two techniques are effective, but rather slow, and the use of needles requires great skill.
The first use of hypochlorite solution as a method to verify the Daphnia resting eggs response to light was described in Pancella and Stross (1963) and lately in Haghparast and Shabani (2012), who exposed the eggs to sodium hypochlorite at a concentration of $1 \%$ for 5 minutes prior to using them in an experiment. Hwan La et al. (2009) also report the use of sodium hypochlorite, at a concentration of $4 \%$ for 20 minutes for the desencapsulation of ephippia. However, we are not aware of any information on hatching rates of resting eggs exposed to different concentrations and exposure time to hypochlorite solution.

Exposure to sodium hypochlorite decapsulates the eggs contained within the ephippium and enables the investigator to select potentially viable eggs and allow to discard seemingly whole but empty (no eggs) ephippia. Moreover, the isolation of resting eggs may promove a higher production of organisms, e.g. used in lab tests or in aquaculture. Another aspect to be considered is that ephippial reproductive rates calculated by ephippial counts alone may be overestimated if ephippial egg abortion or empty ephippia produced by Daphnia are not taken into account, which can interfere in population ecology studies (Conde-Porcuna et al., 2011).

This study aimed to evaluate the abundance of empty ephippia and viable resting eggs of Daphnia from two tropical aquatic ecosystems and the efficiency of some methods for decapsulating resting eggs. The hypothesis leading this work are: a)the immersion on hypochlorite solution will evaluate differences in numbers of resting eggs per ephippia between the ecosystems studied b) treatment of decapsulation of ephippia using the technique of immersion in sodium hypochlorite will be effective for the selection of viable resting eggs.

\section{Material and Methods}

The ephippia used in the experiments were collected from the sediment of Pampulha Reservoir (S 19०55'09', W $43^{\circ}$ 56' 47') and Jacaré Lake (S 19 48' 28.8', N 42 38' 55.5”), located in Minas Gerais, Brazil.

Sediment samples were collected at a single point in the limnetic region (approximately $7 \mathrm{~m}$ ), with a corer-type sampler and the first 10 centimeters were used. The sediment was placed in dark bottles at $4{ }^{\circ} \mathrm{C}$ until the separation of ephippia used in the experiments. For this, the sediment samples were mixed with sucrose solution (1:1) (Onbé, 1978) and the ephippia were pipetted from the supernatant.

\subsection{Number of resting eggs within ephippia}

To assess the natural variation among lakes with respect to number of resting eggs per ephippium (\% of ephippia with 0,1 , or 2 eggs), five ephippia were placed in each well of 12-well culture plates. For each environment, four plates (replicates) with 60 ephippia each were set up, totaling 240 ephippia tested, which were immersed in $4 \%$ sodium hypochlorite to determine the number of eggs present. This concentration allows good and faster visualization of resting eggs 


\subsection{Decapsulation test with hypochlorite}

To assess the effect of time of exposition and hypochlorite solution concentration in decapsulating resting eggs from ephippia and to compare the hatching success of eggs decapsulated, four treatments were used: sodium hypochlorite concentrations of 2 or $4 \%$ with exposure times of 10 or $20 \mathrm{~min}$. The 2 and $4 \%$ concentrations were chosen because they represent the concentrations of commercial bleach and active chlorine, respectively. For this experiment, only ephippia of Pampulha Reservoir were used, because a previous study from Brandão et al. (2014), revealed that Daphnia epphipia from Jacaré Lake presented low hatching rate in laboratory (maximum $8 \%$ ).

The ephippia were placed in a bottle with the bottom covered with a plankton net mesh $(50-\mu \mathrm{m}$ mesh) and kept in the hypochlorite concentration and time used for each treatment. After the treatment, ephippia were washed with a squirt bottle containing $500 \mathrm{~mL}$ of filtered (50- $\mu \mathrm{m}$ mesh) lake water. Eggs that appeared viable were transferred to 12 culture plates. Wells contained $5 \mathrm{~mL}$ of filtered lake water and each received five resting eggs. Each treatment was carried out in triplicate ( 3 plates/treatment $\times 12$ wells/plate $\times 5$ resting eggs/well) for a total of 180 embryos per treatment. Plates were kept in an incubator with a photoperiod of $12 \mathrm{~h}$ and temperature of $24^{\circ} \mathrm{C}$, similar to conditions in the lakes. Hatching was assessed daily for 20 days.

\subsection{Hatching success compared among sets}

To determine whether the sodium hypochlorite method works as well (or better) than other methods used for hatching resting eggs, the following treatments were tested: a) resting eggs obtained from $2 \% / 20 \mathrm{~min}$ sodium hypochlorite treatment $b$ ) resting eggs obtained by manually decapsulating ephippia using dissection needles and c) intact ephippia (assumed to contain two resting eggs each). The eggs and ephippia were placed in culture dishes, two per cell (a total of 24 eggs) and inspected daily for 30 days.

\subsection{Statistical methods}

To evaluate differences between treatments in the hatching rate of resting eggs from Pampulha Reservoir, the proportion of hatched eggs was arcsine square-root-transformed and evaluated by one-way ANOVA. The viability of ephippia from the different lakes, the influence of exposure to hypochlorite on hatching rate and the hatching time of resting eggs from Pampulha Reservoir subjected to the sodium-hypochlorite treatments were evaluated by Kruskal-Wallis test. For statistical analysis and preparation of figures, the STATISTICA 8.0 software was used.

\section{Results}

The ephippia of $D$. laevis, when exposed to sodium hypochlorite became transparent, allowing observation of the number of eggs per ephippium (Figure 1). The exception was the $2 \%$ sodium-hypochlorite treatment for 10 minutes, where some ephippia still had a dark color.

Differences in the number of empty ephippia among the lakes were statistically significant $(\mathrm{KW}-\mathrm{W}(1,8)=5.33$, $P<0.03)$. In Jacaré Lake, $63 \%$ of the ephippia were found to be empty, $14 \%$ contained one egg and $23 \%$ contained two eggs. In Pampulha Reservoir, the number of empty ephippia was considerably lower (16\%), while 25\% contained 1 egg and 59\% contained 2 eggs (Figure 2).

No significant difference was observed in the hatching of resting eggs from Pampulha Reservoir considering the sodium-hypochlorite immersion treatments $(\mathrm{F}(3.80)=0.08$, $P=0.97)$ after 20 days. For the $2 \%$ sodium hypochlorite treatment, the hatching percentages were $64 \pm 4.36 \%$ at 10 minutes and $60 \pm 8.32 \%$ at 20 minutes. For the $4 \%$ sodium hypochlorite treatment, the hatching percentages were $69 \pm 7.02 \%$ at 10 minutes and $62 \pm 10.26 \%$ at 20 minutes (Figure 3). Mean hatching rates higher than $20 \%$ were obtained between fourth and fifth days (KW-H (6.84) $=40.65, P<0.01)$. Only one resting egg hatched after the tenth day, in the $2 \%$ sodium hypochlorite - 20 minutes treatment.
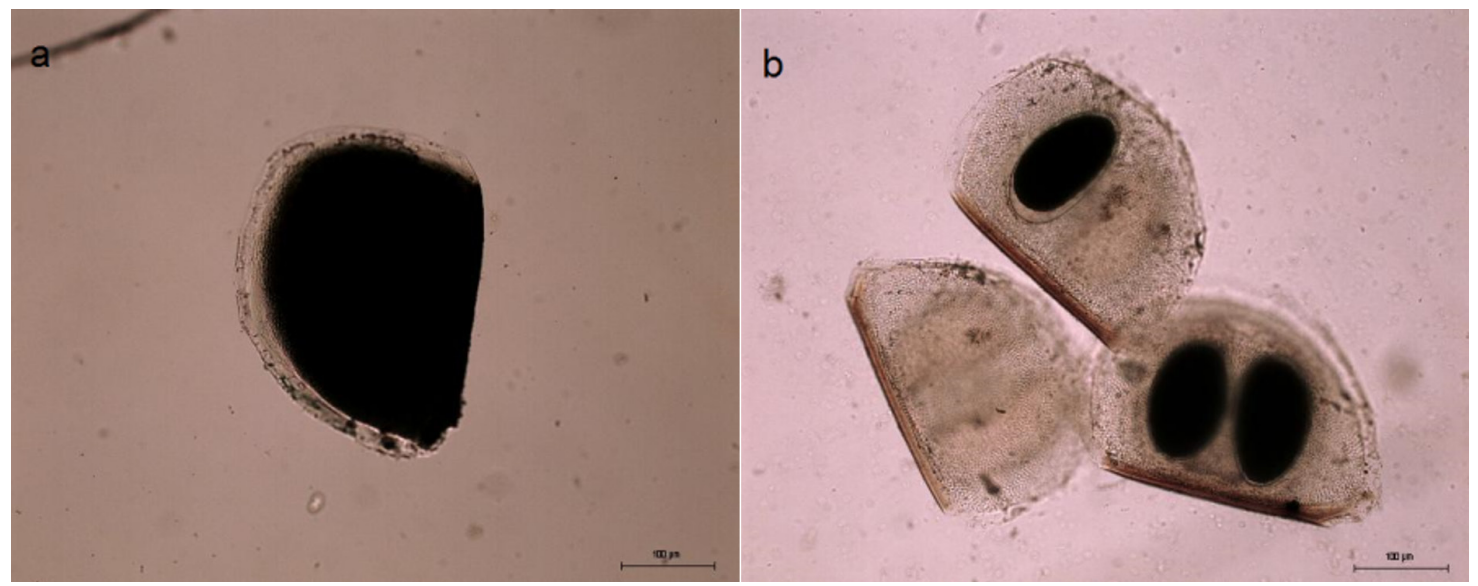

Figure 1. Daphnia laevis ephippia from sediment of Pampulha Reservoir (a) before (dark) and (b) after (transparent) immersion in $2 \%$ sodium hypochlorite. 


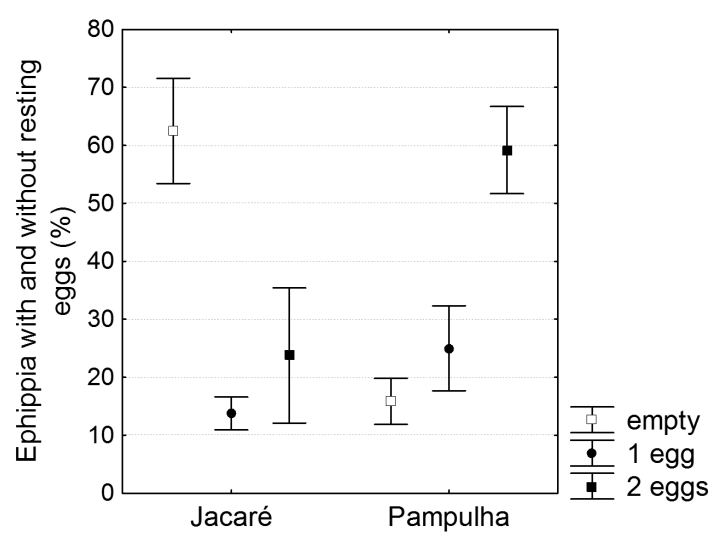

Figure 2. Percentage of healthy resting eggs inside Daphnia laevis ephippia (\%) collected in Jacaré Lake and Pampulha Reservoir $(\mathrm{n}=240$ ephippia/lake). Vertical bars denote 0.95 confidence intervals.

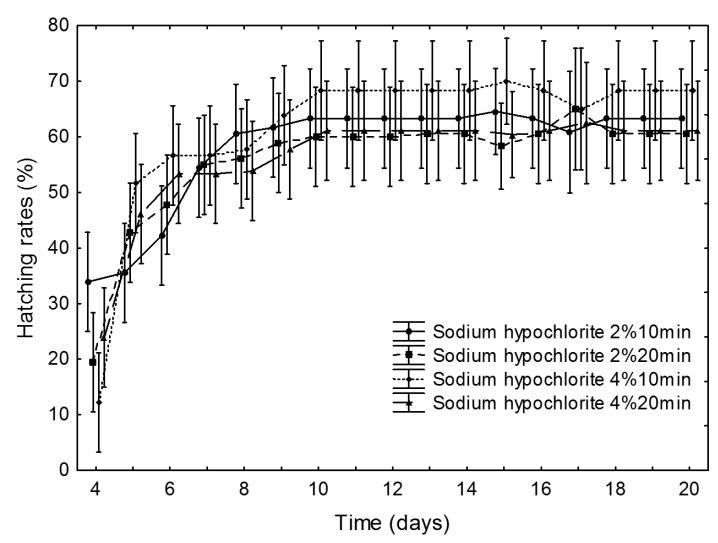

Figure 3. Cumulative hatching of Daphnia laevis resting eggs from Pampulha Reservoir under different conditions of exposure to sodium hypochlorite solution over time $(\mathrm{n}=180 \mathrm{eggs} /$ treatment $)$. Vertical bars denote 0.95 confidence intervals.

Although no significant difference was found in hatching rates among the treatments, exposure to $4 \%$ sodium hypochlorite negatively affected survival of neonates of D. laevis, which were found dead or swimming weakly. Thus, the treatment with $2 \%$ sodium hypochlorite for 20 minutes was chosen for the experiment that compared the hatching success of resting eggs under this treatment with those that were manually decapsulated and resting eggs in intact ephippia.

No significant differences were observed in the hatching rate of resting eggs exposed to hypochlorite and resting eggs manually decapsulated $(\mathrm{KW}-\mathrm{H}(1 ; 42)=0.07, P>0.5)$. However, hatching rates of intact ephippia were much lower than those of treatment with decapsulated eggs. The hatching rates of resting eggs with treatment isolates of ephippia were $47.2 \pm 7.34 \%$ and $53.7 \pm 13.24 \%$, for resting eggs isolated by immersion in hypochlorite and manually isolated, while the hatching rate of ephippia was $11.1 \pm 5.0 \%$ (Figure 4).

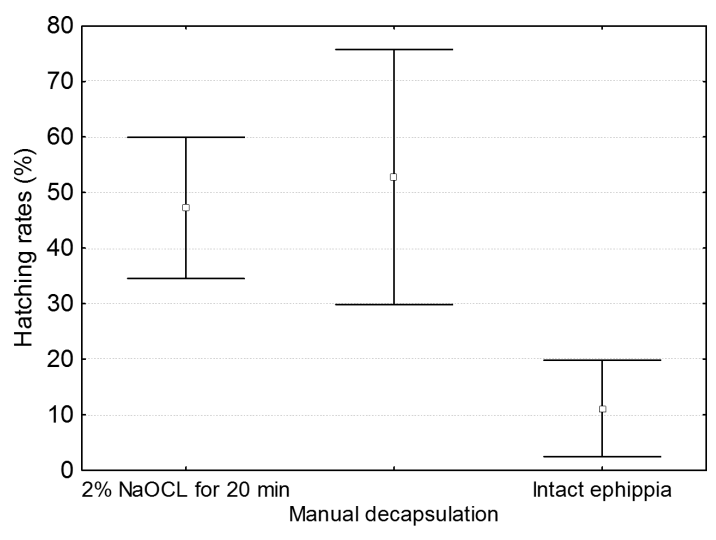

Figure 4. Hatching rates of non-isolated and isolated resting eggs after exposure to from to $2 \%$ sodium hypochlorite for 20 minutes and manually decapsulated. Vertical bars denote 0.95 confidence intervals.

\section{Discussion}

For experiments aiming to evaluate the hatching rates under specific conditions, the isolation the resting eggs is essential since the percentage of eggs within ephippium may vary according to the environment, sampling location, sample period and depth of sediment (Cáceres, 1998; Pérez-Martínez et al., 2012). The ephippium is one of the barriers that protect the resting eggs and it may also mask their visibility (Davison, 1969) because the pigmentation with melanin (Gerrish and Cáceres, 2003). On the other hand, for understanding-population dynamics, the decapsulation may not be necessary; although it may provide complementary information on studies-focusing on diversity of egg bank.

The immersion on hypochlorite solution could evaluate differences in numbers of resting eggs per ephippium between the ecosystems considered, confirming the first hypothesis. Moreover, the hatching rate was underestimated when we used ephippia without assessing the presence of resting eggs. These results reinforce the importance of prior assessment of the viability of ephippia that will be used in experiments that aim at understanding the factors stimulating hatching.

Methods for preliminary assessment of the viability of resting eggs vary greatly but all agree on the importance of using only healthy eggs in hatching tests, no matter what method is used for separating the eggs of the ephippia. Although the manual separation technique requires skill with the use of needles, it has been used in some studies (Cáceres, 1998; Cáceres and Tessier, 2003; Angeler, 2005). Davison (1969), using needles to separate the eggs from the ephippium, showed that only decapsulated ephippia developed (75\%), and the non-decapsulated eggs were observed for many days and never hatched. In the study of Pancella and Stross (1963), the time for hatching of ephippium not treated with hypochlorite was much longer (44 days) than ephippium immersed in hypochlorite for five minutes (three days). Our results showed that resting 
eggs within ephippia immersed in hypochlorite hatching between 4 and 17 days, and intact ephippia between 7 and 20 days.

Thus, decapsulation of the eggs can accelerate the evaluation of factors (temperature, light, predation, etc.) related to the hatching of resting eggs. On the other hand, some studies have shown that the use of hypochlorite can increase the transparency of ephippia and the effects of light on eggs hatching. So, this technique should be used with caution and respecting the objectives of the study.

Experiments using ephippia without prior evaluation are still widely used (Santangelo et al., 2010; Haghparast and Shabani, 2012) but our study showed the importance of this procedure when it is necessary to evaluate the maximum hatching rate of resting eggs or generate new individuals quickly. Moreover, the present study reinforces the importance of separating the eggs from the ephippia, not only to improve the contact of the stimulating factor with the egg, but also to only select eggs that are potentially viable. The lower hatching rates could have occurred because some of the ephippia had fewer than 2 eggs or because eggs within the ephippium are not as sensitive to hatching cues.

Haghparast and Shabani (2012) found differences in the hatching rates of ephippia from Daphnia magna and Daphnia pulex, treated with hypochlorite. D. magna ephippia immersed in $1 \%$ sodium hypochlorite had a higher hatching rate than D. pulex ephippia. However, the authors stated that because they did not separate the eggs contained within the ephippia, this may have adversely affected the results for hatching rates. Paes et al. (2016) found that immersion in $2 \%$ sodium hypochlorite for 20 minutes did not affect the hatching rates of resting eggs of Daphnia ambigua and did not affect survival as they grow and mature.

Sodium hypochlorite efficiently decapsulates ephippia, allowing the researcher to select viable resting eggs and the eggs to hatch more rapidly, thus optimizing studies of this nature. In this study, the best treatment was $2 \%$ sodium hypochlorite for 20 minutes, which did not adversely affect neonate survival, and also allowed viewing of the eggs in all ephippia.

\section{Acknowledgements}

We are grateful to CAPES for a PhD scholarship to the first author. We would like to thank PROGRAD-UFMG for financial support for translation; the personnel from Laboratory of Limnology, Ecotoxicology and Aquatic Ecology (LIMNEA), UFMG, IEF and to the Brazilian Long-Term Ecological Research Project (LTER/UFMG) for financial and logistical support. We are also grateful to the anonymous rewires for the relevant contributions to the manuscript.

\section{References}

ANGELER, D.G., 2005. No diapause prolongation response of Daphnia in the presence of planktivorous mosquitofish (Gambusia holbrooki). Ecological Research, vol. 20, no. 5, pp. 619-622. http://dx.doi.org/10.1007/s11284-005-0075-4.

BRANDÃO, L.P.M., FAJARDO, T., ESKINAZI-SANT'ANNA, E., BRITO, S. and MAIA-BARBOSA, P.M., 2012. Fluctuations of the population of Daphnia laevis Birge 1878: a six-year study in a tropical lake. Brazilian Journal of Biology $=$ Revista Brasileira de Biologia, vol. 72, no. 3, pp. 479-487. http://dx.doi.org/10.1590/ S1519-69842012000300010. PMid:22990818.

BRANDÃO, L.P.M., PUJONI, D.G.F. and MAIA-BARBOSA, P.M., 2014. Seasonal dynamics of Daphnia laevis Birge, 1878 ephippia in a tropical lake with a description of a new methodology for in situ evaluation. Brazilian Journal of Biology $=$ Revista Brasileira de Biologia, vol. 74, no. 3, pp. 642-648. http://dx.doi. org/10.1590/bjb.2014.0069. PMid:25296213.

CÁCERES, C.E. and TESSIER, A.J., 2003. How long to rest: the ecology of optimal dormancy and environmental constraint. Ecology, vol. 84, no. 5, pp. 1189-1198. http://dx.doi.org/10.1890/00129658(2003)084[1189:HLTRTE]2.0.CO;2.

CÁCERES, C.E., 1998. Interspecific variation in the abundance, production, and emergence of Daphnia diapausing eggs. Ecology, vol. 79, no. 5, pp. 1699-1710. http://dx.doi.org/10.2307/176789.

CONDE-PORCUNA, J.M., RAMOS-RODRIGUEZ, E. and PÉREZ-MARTÍNEZ, C., 2014. In situ production of empty ephippia and resting eggs by an obligate parthenogenetic Daphnia population. Journal of Plankton Research, vol. 36, no. 1, pp. 157-169. http://dx.doi.org/10.1093/plankt/fbt072.

CONDE-PORCUNA, J.M., VALDE'S, F.J., ROMO, S. and PÉREZ-MARTÍNEZ, C., 2011. Ephippial and subitaneous egg abortion: relevance for an obligate parthenogenetic Daphnia population. Journal of Limnology, vol. 70, no. 1, pp. 69-75. http:// dx.doi.org/10.4081/jlimnol.2011.69.

DAVISON, J., 1969. Activation of the ephippial egg of Daphnia pulex. The Journal of General Physiology, vol. 53, no. 5, pp. 562-575. http://dx.doi.org/10.1085/jgp.53.5.562. PMid:5814069.

FOX, J.A., 2007. Hatching timing of Daphnia mendotae diapausing eggs of different ages. Fundamental and Applied Limnology, vol. 168, no. 1, pp. 19-26. http://dx.doi.org/10.1127/18639135/2007/0168-0019.

GERRISH, G.A. and CÁCERES, C.E., 2003. Genetic environmental influence on pigment variation in the ephippia of Daphnia pulicaria. Freshwater Biology, vol. 48, no. 11, pp. 1971-1982. http://dx.doi. org/10.1046/j.1365-2427.2003.01136.x.

HAGHPARAST, S. and SHABANI, A., 2012. Hatching Requirements of Daphnia magna Straus, 1820, and Daphnia pulex Linnaeus, 1758 , diapausing eggs from Iranian populations in vitro. Journal Agricultural Science and Technology, vol. 14, pp. 811-820.

HWAN LA, G., JEONG, H.G., KIM, M.C., JOO, G.J., CHANG, K.H. and KIM, H.W., 2009. Response of diapausing eggs hatching to changes in temperature and the presence of fish kairomones. Hydrobiologia, vol. 635, no. 1, pp. 399-402. http://dx.doi. org/10.1007/s10750-009-9913-7.

KAYA, M., CAKMAK, Y.S., BARAN, T., ASAN-OZUSAGLAM, M., MENTES, A. and TOZAK, K.O., 2014. New chitin, chitosan and o-carboxymethyl chitosan sources from resting eggs of Daphnia longispina (Crustacea) with physicochemical characterization, and antimicrobial and antioxidant activities. Biotechnology and Bioprocess Engineering; BBE, vol. 19, no. 1, pp. 58-69. http:// dx.doi.org/10.1007/s12257-013-0488-9. 
KAYA, M., SARGIN, I., TOZAK, K.Ö., BARAN, T., ERDOGAN, S. and SEZEN, G., 2013. Chitin extraction and characterization from Daphnia magna resting eggs. International Journal of Biological Macromolecules, vol. 61, pp. 459-464. http://dx.doi. org/10.1016/j.ijbiomac.2013.08.016. PMid:23973492.

MAIA-BARBOSA, P.M., ESKINAZI-SANT'ANNA, E.M., VALADARES, C.F. and PESSOA, G.C.D., 2003. The resting eggs of zooplankton from a tropical, eutrophic reservoir (Pampulha Reservoir, south-east Brazil). Lakes and Reservoirs: Research and Management, vol. 8, no. 3-4, pp. 269-275. http://dx.doi. org/10.1111/j.1440-1770.2003.00229.x.

ONBÉ, T., 1978. Sugar floatation method for sorting the resting eggs of marine cladocerans and copepods from sea bottom sediment. Bulletin of the Japanese Society for the Science of Fish, vol. 44, pp. 1141. http://dx.doi.org/10.2331/suisan.44.1141

PAES, T.A.S.V., RIETZLER, A.C., PUJONI, D.G.F. and MAIABARBOSA, P.M., 2016. High temperatures and absence of light affect the hatching of resting eggs of Daphnia in the tropics. Anais da Academia Brasileira de Ciências, vol. 88, no. 1, pp. 179-186.

PANARELLI, E.A., CASANOVA, S.M.C. and HENRY, R., 2008. The role of dormant eggs in the recovery of zooplankton community in a marginal lake of the Paranapanema River (São Paulo, Brazil), after a long drought period. Acta Limnologica Brasiliensia, vol. 20, pp. 73-88.

PANCELLA, J.R. and STROSS, R.G., 1963. Light induced hatching of Daphnia resting eggs. Chesapeake Science, vol. 4, no. 3, pp. 135-140. http://dx.doi.org/10.2307/1350746.

PÉREZ-MARTÍNEZ, C., JIMÉNEZ, L., MORENO, E. and CONDE-PORCUNA, J.M., 2012. Emergence pattern and hatching cues of Daphnia pulicaria (Crustacea, Cladocera) in an alpine lake. Hydrobiologia, vol. 707, no. 1, pp. 47-57. http://dx.doi. org/10.1007/s10750-012-1404-6.
ROJAS, N.E.T., MARINS, M.A. and ROCHA, O., 2001. The effect of abiotic factors on the hatching of Moina micrura Kurz, 1874 (Crustacea: Cladocera) ephippial eggs. Brazilian Journal of Biology $=$ Revista Brasileira de Biologia, vol. 61, no. 3, pp. 371-376. http://dx.doi.org/10.1590/S1519-69842001000300005. PMid:11706563.

SANTANGELO, J.M., BOZELLI, R.L., ESTEVES, F.A. and TOLLRIAN, R., 2010. Predation cues do not affect the induction and termination of diapause in small-bodied cladocerans. Freshwater Biology, vol. 55, no. 7, pp. 1577-1586. http://dx.doi. org/10.1111/j.1365-2427.2009.02389.x.

SANTANGELO, J.M., ESTEVES, F.A., MANCA, M. and BOZELLI, R.L., 2014. Disturbances due to increased salinity and the resilience of zooplankton communities: the potential role of the resting egg bank. Hydrobiologia, vol. 722, pp. 103-113. http://dx.doi.org/10.1007/s10750-013-1683-6.

ŚLUSARCZYK, M. and PIETRZAK, B., 2008. To sink or float: the fate of dormant offspring is determined by maternal behaviour in Daphnia. Freshwater Biology, vol. 53, no. 3, pp. 569-576. http://dx.doi.org/10.1111/j.1365-2427.2007.01937.x.

VANDEKERKHOVE, J., DECLERCK, S., BRENDONCK, L., CONDE-PORCUNA, J.M., JEPPESEN. and MEESTER, L., 2005. Hatching of cladoceran resting eggs: temperature and photoperiod. Freshwater Biology, vol. 50, no. 1, pp. 96-104. http://dx.doi.org/10.1111/j.1365-2427.2004.01312.x.

VANÍČKOVÁ, I., SEDA, J. and PETRUSEK, A., 2010. The stabilizing effect of resting egg banks of the Daphnia longispina species complex for longitudinal taxon heterogeneity in long and narrow reservoirs. Hydrobiologia, vol. 643, no. 1, pp. 85-95. http://dx.doi.org/10.1007/s10750-010-0126-x.

ZAFFAGNINI, F., 1987. Reproduction in Daphnia. In: R.H. PETERS and R. BERNARDI, eds. Daphnia. Pallanza: Memorie dell' istituto Italiano di Idrobiologia, pp. 245-284. 